\title{
Hemerotecas de pago en la prensa digital española
}

DESDE QUE LOS DIARIOS ESPAÑOLES de información general llegaran a internet en 1994 de la mano de El periódico de Catalunya, siempre habían ofrecido sus contenidos retrospectivos de forma gratuita. Sin embargo, esta situación pertenece ya al pasado.

En el último trimestre de 2002 algunos de los principales medios con presencia en la red iniciaron la comercialización de sus archivos digitales. $A B C$ y $E l$ periódico de Catalunya fueron los primeros; a ellos se añadieron $E l$ mundo, El país, La vanguardia y Diario de Navarra. Otros como por ejemplo el guipuzcoano Diario vasco y El correo digital lo tienen también previsto para un futuro no muy lejano.

\section{elPeriódico}

\section{Se preveía}

La tendencia a hacer de las hemerotecas servicios de pago no es nueva, tal y como se apuntaba en el artículo "Las hemerotecas digitales de la prensa en internet", publicado en esta misma revista en mayo del año 2000. Está ampliamente extendida entre los rotativos norteamericanos así como entre los principales europeos. En España, hasta finales de 2002 ningún medio de información general había seguido esta línea, aunque existían algunos precedentes. El diario económico Expansión era uno de ellos. El deportivo Marca no comercializa su hemeroteca pero sí ofrece desde hace algunos años Marcamedia, un servicio de venta de imágenes publicadas en sus ediciones impresa y electrónica.

Según estudios sobre la situación de las hemerotecas digitales,

Por Àngels Jiménez López

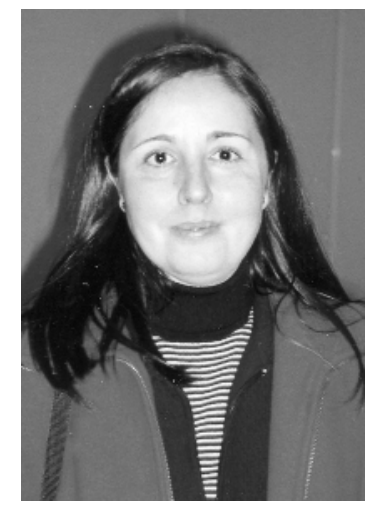

Àngels Jiménez

realizados por miembros del Area de Documentación de la Univ. Autónoma de Barcelona, de los más de 170 diarios impresos publicados en España, 119 poseen en la actualidad edición en internet y de éstos, 103 cuentan con servicio de acceso a información retrospectiva. Este dato pone de manifiesto que el número de cabeceras que han optado por comercializar su hemeroteca es todavía poco significativo; sin embargo, la presencia de estas iniciativas refleja la tendencia de la prensa española a sumarse a la ya generalizada en otros países.

\section{El cobro como alternativa}

Las causas que han motivado la puesta en marcha de servicios de pago son diversas. Una de ellas es el hecho de no haberse cumplido las expectativas de los medios en materia de contratación publicitaria. La oferta de sitios web con espacios para este fin es tan amplia que ha desatado una gran competencia, dificultando la captación de anunciantes y obligando a abaratar los precios. Otra de las causas se encuentra en la actitud de los responsables de las ediciones digitales, cada vez menos dispuestos a aceptar que empresas de toda índole se beneficien gratuitamente de las informaciones publicadas para proveer de contenidos sus sedes web, intranets o para elaborar resúmenes de prensa. A estas razones debe añadirse una tercera: el imperativo de alcanzar niveles de rentabilidad que garanticen la pervivencia de las ediciones en línea.

Aún es pronto para aventurar el éxito o fracaso de los servicios de pago. No lo es, sin embargo, para afirmar que dependerá del valor añadido que proporcionen. En el caso de las hemerotecas dicho valor vendrá determinado principalmente por el volumen y variedad de la información accesible, el período cronológico cubierto o la versatilidad y eficiencia de los sistemas de recuperación.

\section{Diferentes enfoques}

Actualmente los medios que han implantado servicios de pago no coinciden en la forma de plantear su oferta:

$A B C$ : comercializa un archivo de noticias que cubre desde 1996. El cobro se realiza por artículo (0,75 euros/unidad).

El periódico de Catalunya: su archivo arranca en enero de 2000 y al igual que $A B C$ cobra por artículo adquirido. El precio resulta algo más económico que en aquél $(0,5$ euros) pero su cobertura temporal es también menor.

\section{EL PAIS.es}

Diario de Navarra: la suscripción a su hemeroteca, cuya cobertura cronológica se inicia en el año 2001, es indesligable de la contratación de otros servicios. Ofrece un paquete que incluye, además del acceso al fondo retrospectivo, la edición impresa del día en formato pdf, una base de datos de necroló- 
gicas, envío de titulares por correo electrónico y una fonoteca constituida por los informativos de Cope-Navarra de los últimos 12 meses. La suscripción puede ser trimestral, semestral o anual $(18,30 \mathrm{o}$ 50 euros, respectivamente).

\section{«El país, a partir de una reestructuración de su sede web, co- mercializó la práctica totalidad de sus con- tenidos y servicios»}

El mundo: comercializa la hemeroteca de su edición impresa, que incluye noticias desde enero de 1994. Ofrece varias opciones de suscripción cuyo coste oscila entre 30 y 97 euros, aunque también cuenta con bonos para la adquisición de artículos sueltos. En su sede web el periódico dispone además de un archivo retrospectivo de la edición digital. Éste es gratuito y cubre desde julio de 2002.

El país: su apuesta constituye sin duda la más ambiciosa de todas. A partir de una reestructuración de su sede web comercializó la práctica totalidad de sus contenidos y servicios. Ofrece un archivo de noticias desde 1976, año de aparición del diario. Se puede acceder no sólo a los fondos retrospectivos de El país sino también al de otras publicaciones del grupo Prisa. Pueden adquirirse artículos al precio de 0,2 euros cada uno, así como ejemplares en formato pdf desde julio de 2001 (0,5 euros/unidad). Mediante una suscripción anual (de 80 euros) o semestral (de 50) se tiene acceso a la totalidad de los contenidos.

La vanguardia: se trata del periódico español con el mayor fondo histórico accesible a través de internet. Ha digitalizado toda su colección y creado una hemeroteca de ejemplares en pdf desde su inicio en 1881. Además, cuenta con un archivo de noticias que arranca de 1999 y está disponible solamente para suscriptores de los servicios en línea. El acceso a la hemeroteca histórica en pdf puede hacerse mediante el sistema de pago por ejemplar (3 euros/unidad) o bien al contratar el paquete de servicios en línea. Éste incluye: acceso a la hemeroteca, consultas al archivo de noticias, edición del día en pdf, recepción de boletines por correo electrónico y servicio de alerta, entre otros. Su precio es de 80 euros por la suscripción anual y 50 por la semestral.

\section{Futuro}

Ahora se inicia para la prensa digital un periodo de espera, necesario para poder evaluar de forma objetiva la rentabilidad de los servicios y observar en qué medida nuestra cultura informacional se adapta al nuevo modelo de pago. Resulta lógico que hayan sido los periódicos con mayores recursos los primeros en dar el paso hacia la comercialización, sobre todo si se tiene en cuenta la inversión que puede exigir la digitalización de colecciones retrospectivas en algunos casos. Con toda probabilidad, y si se constata el éxito de los servicios de pago, otras muchas cabeceras seguirán el ejemplo. El que las hemerotecas se encuentren entre los primeros servicios comercializados no resulta un hecho fortuito. La experiencia de otros países y la nuestra propia han puesto de manifiesto el alto interés que tiene para numerosos profesionales y sectores de actividad la información periodística retrospectiva. Por ello parece previsible que además de las hemerotecas los medios de comunicación inicien en un futuro próximo la comercialización de otros fondos, como por ejemplo, los archivos fotográficos.

Àngels Jiménez López, Universitat

Autònoma de Barcelona (UAB)

angels.jimenez@uab.es 